\title{
Family Support in Victims of Children of Sexual Violence in Indonesia
}

\author{
Sofia Februanti", Tetet Kartilah \\ Diploma 3 Nursing Diploma Study Program, Health Polytechnic of Tasikmalaya, Indonesia \\ Corresponding Author - Sofia Februanti; sofiafebruanti@gmail.com \\ Received 19 July 2019; \\ Accepted 13 August 2019;
}

Published 21 August 2019

\begin{abstract}
Every child has the right to survival, to grow and develop and has the right to protection from violence and discrimination. However, there are still many problems faced today, especially in Indonesia.This study aims to determine family support for girls who are victims of sexual violence. This study uses qualitative research methods with an in-depth interview approach with audio recordings, field notes, documentation. Participants in this study were families who had family members/girls victims of sexual violence. Sampling using purposive sampling technique that fits the inclusion criteria. The interview was recorded and made the word for word transcription. Transcripts of interviews were analyzed by Colaizzi's steps. The results of the study showed that there were four themes namely family informational support, family assessment support, family instrumental support, family emotional support. Family support is needed by girls who are victims of sexual violence to help their future survival
\end{abstract}

Keywords: girls, family support, sexual violence.

\section{Introduction}

Children are unique creatures and not miniature adults. For that child need special attention and opportunities as broad as possible to grow and develop optimally both physically, spiritually and socially. This child's growth and development can be fulfilled by his family, especially parents. Children who are victims of sexual violence can interfere with their growth and development.

Cases of sexual violence against women are increasingly sad. Not only is the quantity of violence increasing, but also the quality of sexual violence against women also shows a surge in numbers. In 2015, there were 218 cases, in 2016 there were 120 cases, and in 2017 there were 116 cases of sexual violence against children ${ }^{[1]}$. Whereas in 2018, 117 children were victims of sexual violence in February ${ }^{[2]}$. Forms of sexual violence against women include incest, rape, sexual abuse, cyber-based violence (women become objects of pornography), sexual intimidation, sexual harassment, sexual exploitation, trafficking of women, forced prostitution to slavery. handling cases of sexual violence against women is important. Victims of sexual violence generally experience a series of previous acts of violence ${ }^{[3]-[4]-[5]}$.

Sexual violence harms victims, especially girls. These negative impacts include increased vulnerability to various physical and mental problems, ranging from depression, unwanted pregnancy, to cardiovascular disease, diabetes, and sexually transmitted diseases, including HIV, self-blame children, shame, negative social reactions when disclosure victims ${ }^{[6]-[5]}$.
Cases of sexual violence in girls need the support of various parties in the form of comprehensive, holistic and integrated handling of victims by various related sectors such as government, nongovernmental organizations, the private sector and the community including families ${ }^{[7]}$. Health centers as primary health care facilities can receive, handle cases of sexual violence in children or if necessary refer to hospitals to get further treatment, but do not have a special program to prevent sexual violence ${ }^{[8]}$.

Victims of sexual violence need family support as well as social support ${ }^{[9]}$. The impact experienced by girls victims of sexual violence greatly affects the lives and development of children. The impact of depression on victims of sexual violence can be reduced by family mediation and the level of satisfaction with family relationships is getting better ${ }^{[10]}$. Therefore, family support is needed in handling children both physically and psychologically.

\section{Method}

\section{Design}

This study uses a qualitative method with a phenomenological approach. The research with the phenomenology approach aims to develop the meaning of the experience of living social environments in providing support to girls who are victims of sexual violence.

\section{Setting and Sample}

Participants were selected by a Purposive technique with the criteria of parents or family members of girls who were victims of 
sexual violence with ages 6 to 17 who lived at home but were not perpetrators of sexual violence.

The number of participants involved in this study was two people. The participant search process was carried out by researchers with the help of the social service, the Regional Child Protection Commission of the city of Tasikmalaya, and the Integrated Service Center for Women and Children Empowerment (P2TP2A) in the Tasikmalaya region.

\section{Data Collection}

The data collection strategy used in this qualitative research is indepth interviews (in-depth interviews), observations and field notes. At the interview, the strategy used was an open-ended interview. Interviews were conducted face-to-face and before the researcher had compiled the guideline questions so that they could be developed more deeply but still by the research objectives.

\section{Ethical Considerations}

Ethical approval was issued by the health research ethics committee at the Health Polytechnic of the Ministry of Health in Tasikmalaya. Before the interview begins, the participants are given an explanation by the researcher about the participants' goals, procedures, and rights. Participants who agreed to participate in the study were then asked to sign an informed consent. Thus the researcher can start data collection.

\section{Data Analysis}

The stages of the data analysis process are carried out according to the steps of Colaizzi, which is making data transcripts, creating categories, and tracing the themes and sub-themes.

\section{Result}

Participants who participated in this study consisted of two family members, can be seen in table 1

Table 1: Demographic characteristics of study participants

\begin{tabular}{|l|l|l|l|l|}
\hline $\begin{array}{l}\text { Partici } \\
\text { pant } \\
\text { No. }\end{array}$ & Gender & Age & Work & $\begin{array}{l}\text { Relationship } \\
\text { with the } \\
\text { victim }\end{array}$ \\
\hline P1 & Man & $\begin{array}{l}73 \text { years } \\
\text { old }\end{array}$ & entrepreneur & Grandfather \\
\hline P2 & Women & $\begin{array}{l}58 \text { years } \\
\text { old }\end{array}$ & entrepreneur & $\begin{array}{l}\text { Adoptive } \\
\text { mother }\end{array}$ \\
\hline
\end{tabular}

The themes that arise from the collected data are informational support, assessment support, instrumental support, family emotional support.

\section{Informational Support}

Girls victims of sexual violence can experience physical and emotional and behavioral disorders. Participants reveal in the form of:

"... after knowing that an was pregnant, I suggested that An An go to the Puskesmas, then find out who impregnated my granddaughter, then to marry ..." (P1)

Families can provide support to girls who are victims of sexual violence including communication networks and shared responsibilities, including providing solutions to problems, providing advice, direction, advice or feedback about what someone is doing. Families can provide information by suggesting doctors, therapies that are good for themselves and specific actions for individuals to fight stress. In this information support the family as a collector of information and information. This was conveyed by participant 2 :

"... after this incident, I immediately examined An V's entire body, especially his legs, ... then I looked for the perpetrators' parents to educate their children properly, not to harm people ..." (P2)

\section{Assessment Support}

Girls victims of sexual violence can experience physical and emotional and behavioral disorders. Participants revealed assessment support for girls who were victims of sexual violence, including:

"... An An looks silent, depressed, like being sad ... then I asked why this month didn't ask for money to buy sanitary napkins ... the answer to this question surprised me ... then I asked who did abuse ... then I asked for help from the RW chief to look for the perpetrators of abuse at An ... "(P1).

Families can provide support to girls who are victims of sexual violence including help to individuals to understand depression events well and also the source of depression well and coping strategies that can be used in dealing with stressors. This support is also support that occurs when there is an expression of positive judgment on the individual. Individuals have someone they can talk to about their problems, going on through the expression of positive individual expectations to other individuals, encouragement, approval of someone's ideas or feelings and a positive comparison with someone else.

"... after the incident, I saw An D like experiencing a setback in terms of writing and reading ... then I taught again how to read and write so that his memory was distracted ..." (P2).

\section{Instrumental Support}

Girls victims of sexual violence can experience physical and emotional and behavioral disorders.

".... When An An is going to give birth, I deliver and help with the need to go to the hospital, but thank God for the problem of buying formula milk and baby's needs there is something to help ..." (P1).

Instrumental support by the family includes the provision of physical support such as services, financial and material assistance in the form of real assistance (instrumental support, material support) a condition where objects or services will help solve practical problems including direct assistance such as when someone gives or lends money, helps with work everyday, convey messages, provide transportation, maintain and care for illness, or experience depression that can help solve problems. Participant 2 revealed instrumental support for girls victims of sexual violence, among others in the form of

"... after the incident, my child was gloomy, sad, so he did not want to write and read, so I taught him to write and read again ... sometimes if I eat food, even though I have not once fed when eating because my child has grown up ... but after this incident, my child became difficult to eat ... the school had to be escorted by an ojek ... "(P2)

\section{Emotional Support}


Girls who are victims of sexual violence can experience depression due to their experiences. During the depression, individuals often suffer emotionally, sadness, anxiety, and loss of self-esteem. Participants expressed support for girls who were victims of sexual violence in the form of:

"... after the incident, I still paid attention to my grandson, especially the fulfillment of food, his health including his fetus, I delivered his pregnancy check-up to the health center ... because after this incident, I became affectionate to the fetus, not to happen to the fetus ... "(P1)

"... I pay attention to the problem of education ... why does my child not want to write and read ... then I teach again writing and reading ... then I like stroking his head ... sometimes I like to cry because I feel sorry to see that child, his mother has died now there is an incident like this ... finally, I always encourage if I will go to school and recite... I am often invited to talk for fear of something.... "(P2)

Emotional support given by the family can give individuals a feeling of comfort, feeling love, empathy, trust, attention so that the individual who receives it feels valuable. In this emotional support, the family can provide a place of rest and encouragement.

\section{Conclusion}

Family support in the form of informational support, assessment support, instrumental support, emotional support is needed by girls who are victims of sexual violence. Family support is needed so that victims can continue their next survival.

\section{Acknowledgment}

Thank you to the head of the human resource development center (PPSDM) ministry of health and Director of the Health Polytechnic of the Ministry of Health, Tasikmalaya who facilitated the funding of this research

\section{Bibliography}

[1] D. Setyawan, "Tahun 2017, KPAI Temukan 116 Kasus Kekerasan Seksual Terhadap Anak," Jakarta, 2017.

[2] N. A. Akbar, "Sepanjang tahun 2018 ada 100 lebih korban kekerasan seksual terhadap anak di Indonesia," Jakarta, Mar-2018.

[3] N. A. R. Astuti, "Komnas Perempuan: Laporan Kekerasan Seksual Meningkat di 2018," Jakarta, Mar2019.

[4] Komnas Perempuan, 15 Bentuk Kekerasan Seksual sebuah pengenalan. Jakarta: Komnas Perempuan, 2013.

[5] M. J. Breiding, S. G. Smith, K. C. Basile, M. L. Walters, J. Chen, and M. T. Merrick, "Prevalence and Characteristics of Sexual Violence, Stalking, and Intimate Partner Violence Victimization - National Intimate Partner and Sexual Violence Survey, United States, 2011," Atlanta, USA, 2015.

[6] C. Kennedy and K. A. Prock, “I Still Feel Like I Am Not Normal': A Review of the Role of Stigma and Stigmatization Among Female Survivors of Child Sexual Abuse, Sexual Assault, and Intimate Partner Violence," Trauma, Violence, Abus., vol. 19, no. 5, 2018.
[7] S. Februanti and T. Kartilah, "SOCIAL SUPPORT IN VICTIMS OF CHILDREN OF SEXUAL VIOLENCE," Malaysian J. Nurs., vol. 10, no. 4, 2019.

[8] T. Kartilah, S. Februanti, B. Sakti, and U. A. Hidayat, "The Role of Community Health Centres (PUSKESMAS) in the implementation of sexual violence for school age children in elementary school," JMCRH, vol. 1, no. 2, pp. 341-350, 2018.

[9] N. Koçtürk and F. Bilge, "Social Support of Adolescent Survivors of Child Sexual Abuse and Sexual Revictimization in Turkey," J. Child Sex. Abus., vol. 27, no. $1,2018$.

[10] Kyu-ManHan et al., "Intimate partner violence and incidence of depression in married women: A longitudinal study of a nationally representative sample," J. Affect. Disord., vol. 45, 2019.

[11] S. M. Frías and M. C. Agoff, "Between Support and Vulnerability: Examining Family Support Among Women Victims of Intimate Partner Violence in Mexico,” J. Fam. Violence, vol. 30, no. 3, 2015.

[12] T. E. Sutton and L. G. Simons, "Sexual Assault Among College Students: Family of Origin Hostility, Attachment, and the Hook-Up Culture as Risk Factors," J. Child Fam. Stud., vol. 24, no. 10, 2015.

[13] J. A. Reid, J. Huard, and R. A. Haskell, "Familyfacilitated juvenile sex trafficking," J. Crime Justice, vol. 38, no. 3, 2015.

[14] M. Hébert, F. Lavoie, and M. Blais, "Post Traumatic Stress Disorder / PTSD in adolescent victims of sexual abuse: resilience and social support as protection factors," SciELO public Heal., pp. 685-694, 2014.

[15] Ab. R. A. Manaf and N. Mokhtar, "Social Support for Child Abuse Cases in Institutional Care," J. Soc. Dev. Sci., vol. 4, no. 11, pp. 508-513, 2013.

[16] C. Kennedy and K. A. Prock, "'I Still Feel Like I Am Not Normal' A Review of the Role of Stigma and Stigmatization Among Female Survivors of Child Sexual Abuse, Sexual Assault, and Intimate Partner Violence," sage journals, 2016.

[17] K. M. Sylaska and K. M. Edwards, "Disclosure of Intimate Partner Violence to Informal Social Support Network Members A Review of the Literature," sage journals, vol. 15, no. 1, 2014.

[18] D. Collin-Vézinaa, M. D. La Sablonnière-Griffin, A. M. Palmer, and L. Milne, "A preliminary mapping of individual, relational, and social factors that impede disclosure of childhood sexual abuse," Child Abuse Negl., vol. 2015, no. 43, pp. 123-134, 2015.

[19] V. Schönbucher, T. Maier, M. Mohler-Kuo, U. Schnyder, and A. M. Landolt, “Adolescent Perspectives on Social Support Received in the Aftermath of Sexual Abuse: A Qualitative Study," Arch. Sex. Behav., vol. 43, no. 3, pp. 571-586, 2014.

\section{Author Profile}

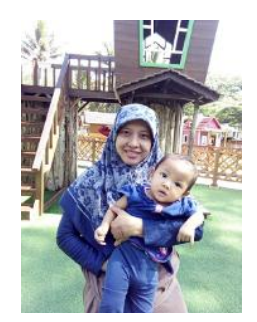


Sofia Februanti received the title S. Kep., Ns. and M. Kep from the University of Indonesia, Nursing Science Faculty. During 2003 until now working as a nursing lecturer, with specialization in maternity nursing majoring in nursing health polytechnic ministry of health Tasikmalaya. 